\title{
Kontribusi Pembangunan Infrastruktur Terhadap Pertumbuhan Ekonomi Dan Ketimpangan Pendapatan Di Indonesia Tahun 2010-2019
}

\author{
(Contribution Of Infrastructure Development To Economic Growth And Inequality Of Income In \\ Indonesia 2010-2019)
}

Purim Kharisman Hulu ${ }^{1 *}$, Krismanti Tri Wahyuni ${ }^{2}$

${ }^{1,2}$ Politeknik Statistika STIS

Jalan Otto Iskanardinata No.64C, Kota Jakarta Timur, DKI Jakarta 1330

E-mail: 211709944@stis.ac.id

\begin{abstract}
ABSTRAK
Upaya mencapai pembangunan berkelanjutan tidak hanya memperhatikan aspek ekonomi melalui peningkatan perekonomian, namun turut memperhatikan aspek sosial dengan adanya pemerataan distribusi pendapatan. Pertumbuhan ekonomi Indonesia yang selalu tumbuh positif, nyatanya tidak mengakibatkan pendapatan dapat terdistribusi secara merata dalam masyarakat. Ketimpangan pendapatan masih menjadi masalah utama yang ditunjukkan dengan tingginya rasio gini Indonesia. Agar dapat meningkatkan perekonomian dan pemerataan distribusi pendapatan, infrastruktur memiliki peranan yang penting dalam dua aspek tersebut. Penelitian ini bertujuan untuk menganalisis hubungan antara pertumbuhan ekonomi dengan ketimpangan pendapatan, serta pengaruh infrastruktur dan determinan lainnya pada 34 provinsi di Indonesia. Berdasarkan hasil analisis, terdapat hubungan simultan antara pertumbuhan ekonomi dan ketimpangan pendapatan, namun ketimpangan pendapatan tidak berpengaruh signifikan terhadap pertumbuhan ekonomi. Infrastruktur sanitasi, jalan, kesehatan, dan listrik berpengaruh signifikan terhadap pertumbuhan ekonomi, sedangkan telekomunikasi tidak berpengaruh signifikan. Variabel Penanaman Modal Asing (PMA) dan infrastruktur pendidikan berpengaruh signifikan terhadap ketimpangan pendapatan, namun tidak signifikan untuk variabel Tingkat Partisipasi Angkatan Kerja (TPAK).
\end{abstract}

Kata kunci: pembangunan berkelanjutan, pertumbuhan ekonomi, ketimpangan pendapatan, infrastruktur, simultan

\begin{abstract}
Efforts to achieve sustainable development do not only notice to the economic aspect through improving the economy, but also pay attention to the social aspect with an even distribution of income. Indonesia's economic growth which always grows positively, in fact does not result in income being evenly distributed in society. Income inequality is still a major problem as indicated by Indonesia's high Gini ratio. In order to improve the economy and equitable distribution of income, infrastructure has an important role in these two aspects. This study aims to analyze the relationship between economic growth and income inequality, as well as the influence of infrastructure and other determinants in 34 provinces in Indonesia. Based on the results of the analysis, there is a simultaneous relationship between economic growth and income inequality, but income inequality has no significant effect on economic growth. Sanitation infrastructure, roads, health, and electricity have a significant effect on economic growth, while telecommunications have no significant effect. The variables of Foreign Investment (PMA) and education infrastructure have a significant effect on income inequality, but are not significant for the Labor Force Participation Rate (TPAK) variable.
\end{abstract}

Keywords: sustainable development, economic growth, income inequality, infrastructure, simultaneous

\section{PENDAHULUAN}

Pembangunan berkelanjutan adalah suatu proses perkembangan yang meningkatkan tingkat perekonomian, menjaga keadaan sosial dan kelestarian lingkungan demi kebermanfaatan generasi sekarang dan generasi di masa depan (Rogers et al., 2007). Untuk mencapai pembangunan yang berkelanjutan dibutuhkan pembangunan yang tidak hanya memerhatikan pembangunan ekonomi saja, namun turut memerhatikan aspek lingkungan dan sosial guna menjamin kesejahteraan generasi masa kini dan generasi di masa depan. Salah satu tujuan utama dalam pembangunan berkelanjutan adalah tercapainya pemerataan. Pembangunan yang berorientasi pada pemerataan didasari oleh beberapa hal, salah satunya adalah pemerataan kondisi perekonomian yang dicapai dengan keseimbangan distribusi kesejahteraan. Tujuan pemerataan ini diwujudkan dalam tujuan kesepuluh dari Sustainable Development Goals (SDGs) untuk mengurangi ketimpangan di dalam negara (United Nations, 2014). Dengan demikian, pelaksanaan pembangunan 
seharusnya diarahkan pada bidang-bidang yang mampu meningkatkan kesejahteraan masyarakat di setiap lapisan.

Kemajuan pembangunan berkelanjutan dapat ditunjukkan oleh indikator pertumbuhan ekonomi dan ketimpangan pendapatan. Adapun hubungan kedua variabel dapat dijelaskan melalui teori kurva kuznet yang digambarkan dengan huruf $\mathrm{U}$ terbalik, serta dapat dijelaskan dengan hubungan dua arah yang saling mempengaruhi satu sama lain. Tambunan (2003) menjelaskan bahwa kedua variabel tersebut memiliki korelasi yang sangat kuat satu sama lain. Pertumbuhan ekonomi menjadi suatu tolak ukur keberhasilan programprogram pembangunan (Todaro dan Smith, 2004). Pertumbuhan ekonomi memberikan gambaran perkembangan aktivitas dalam perekonomian yang dapat menyebabkan barang dan jasa yang dihasilkan dalam masyarakat meningkat (Sukirno, 2008). Salah satu aspek yang dapat meningkatkan pertumbuhan ekonomi pada suatu wilayah adalah melalui ketersediaan infrastruktur. Infrastruktur diyakini mampu menggerakkan sektor-sektor lain untuk berkembang, meningkatkan konsumsi masyarakat dan mendorong kegiatan produktif yang secara langsung maupun tidak langsung menentukan pertumbuhan ekonomi di suatu negara (Awandari dan Indrajaya, 2016). Upaya membangun infrastruktur juga menjadi perhatian utama Pemerintah Indonesia. Hal ini tertuang dalam kegiatan Masterplan Percepatan dan Perluasan Pembangunan Ekonomi Indonesia (MP3EI) yang difokuskan melalui pembangunan kegiatan utama dan pembangunan pada infrastrukur (MP3EI, 2011).

Indikator lainnya yang dapat menggambarkan pembangunan selain pertumbuhan ekonomi adalah ketimpangan pendapatan. Pembangunan ekonomi sendiri dikatakan tercapai jika pendapatan per kapita masyarakat terus bertambah pada tingkat yang cukup cepat. Di lain pihak, peningkatan pertumbuhan ekonomi belum tentu diikuti dengan peningkatan pendapatan per kapita (Sukirno, 2006). Oleh karena itu, pihak-pihak yang berperan terhadap peningkatan pertumbuhan ekonomi perlu dianalisis lebih lanjut. Apabila pertumbuhan ekonomi dihasilkan oleh sebagian kecil penduduk pada suatu wilayah maka hasilnya hanya akan dinikmati sebagian kecil penduduk saja dan berpotensi meningkatkan ketimpangan pendapatan (Todaro dan Smith, 2004).

Dengan tingkat pertumbuhan ekonomi yang selalu tumbuh positif di sekitar angka 5 persen setiap tahunnya, tidak mengakibatkan pendapatan dapat terdistribusi secara merata (World Bank, 2015). Hal ini dapat digambarkan melalui angka rasio gini Indonesia. Angka rasio gini Maret tahun 2019 sebesar 0,380 dan menurun dengan lambat bila dibandingkan dengan tahun sebelumnya. Keadaan ketimpangan ini juga sejalan dengan tidak tercapainya Rancangan Pembangunan Jangka Menengah Nasional (RPJMN) 2015-2019 yang menetapkan rasio gini untuk akhir tahun 2019 sebesar 0,36. Sayangnya, pada akhir tahun tersebut rasio gini Indonesia masih berada pada angka 0,38. Lembaga keuangan dunia, World Bank turut menyatakan bahwa dalam 15 tahun terakhir, pertumbuhan ekonomi Indonesia telah mengalami penguatan. Akan tetapi, kebermanfaatan dari pertumbuhan ekonomi ini hanya dirasakan oleh 20 persen penduduk terkaya dan sekitar 80 persen penduduk rawan tertinggal (World Bank, 2015). Selain itu, Laporan Ketimpangan Indonesia yang dipublikasikan oleh LSM Oxfam menyebutkan bahwa Indonesia merupakan salah satu negara yang memiliki ketimpangan paling parah di dunia (Oxfam, 2017). Permasalahan ketimpangan juga terjadi pada antar provinsi di Indonesia. Penelitian Maryaningsih et al., (2014) menyebutkan bahwa pertumbuhan ekonomi Indonesia telah mampu meningkatkan rata-rata pendapatan per kapita riil nasional, akan tetapi belum terdapat pemerataan pendapatan riil antar provinsi di Indonesia. Perbedaan kondisi antar provinsi tersebut dapat mengakibatkan perbedaan perekonomian antar wilayah semakin besar dan berdampak pada ketimpangan antar daerah apabila tidak disertai dengan tindakan yang tepat.

Agar pembangunan berkelanjutan tercapai, pemerataan distribusi pendapatan harus dipandang serius. Ketidakmerataan pendapatan yang terus dibiarkan hanya akan menghasilkan berbagai permasalahan baru pada masa depan seperti inefisiensi ekonomi, menambah jumlah penduduk miskin, melemahkan stabilitas sosial dan solidaritas serta memperkuat kekuatan politis golongan kaya yang dapat menciptakan ketidakadilan bagi masyarakat (Todaro dan Smith, 2004). Berdasarkan uraian masalah di atas, penelitian ini bertujuan untuk: (1) Memberikan gambaran umum mengenai pertumbuhan ekonomi dan ketimpangan pendapatan di Indonesia, (2) Menganalisis hubungan timbal balik dan pengaruh antara pertumbuhan ekonomi dan ketimpangan pendapatan, (3) Menganalisis pengaruh dari pembangunan infrastruktur terhadap pertumbuhan ekonomi dan ketimpangan pendapatan di Indonesia. 


\section{METODE}

\section{Landasan Teori}

Pertumbuhan ekonomi dijelaskan sebagai perkembangan kegiatan dalam perekonomian yang menyebabkan barang dan jasa yang dihasilkan dalam masyarakat meningkat (Sukirno, 2006). Pertumbuhan ekonomi pada suatu wilayah dapat dijelaskan melalui tiga faktor atau komponen utama yakni: akumulasi modal yang melingkupi semua jenis investasi, pertumbuhuan penduduk, dan perkembangan teknologi. Akumulasi modal melalui investasi yang menunjang perekonomian seperti infrastruktur memiliki peran penting dalam menggerakkan perekonomian suatu negara. Infrastruktur turut memiliki peranan penting bagi masyarakat untuk mempermudah aktivitas ekonomi masyarakat dan meningkatkan produktivitas serta pendapatan. Infrastruktur dalam ilmu ekonomi merupakan wujud dari modal publik yang terbentuk melalui investasi yang dilaksanakan pemerintah yang meliputi jembatan, jalan, dan sistem saluran pembuangan (Mankiw, 2013). Menurut World Bank (1994), infrastruktur dapat dikategorikan atas tiga bagian, yakni infrastruktur ekonomi, infrastruktur sosial, dan infrastuktur administrasi/institusi.

Pendapatan dapat dijelaskan sebagai gambaran tingkat kemampuan seseorang untuk memenuhi kebutuhan materinya dalam satuan waktu tertentu, umumnya per bulan. Distribusi pendapatan adalah sebuah konsep yang menjelaskan mengenai penyebaran pendapatan setiap orang atau rumah tangga didalam masyarakat (Sukirno, 2006). World Bank (2009), menyebut ketimpangan pendapatan sebagai konsep yang lebih luas daripada kemiskinan, ketimpangan pendapatan didefenisikan atas seluruh populasi. Fenomena ketimpangan pendapatan dapat dijelaskan melalui Teori Neo-Klasik yang menjelaskan bagaimana pentingnya peranan kapital, yang dapat direpresentasikan melalui investasi.

\section{Data dan Sumber Data}

Data yang digunakan merupakan data sekunder yang diperoleh melalui Badan Pusat Statistik (BPS) dalam kurun waktu 2010 sampai dengan 2019 pada 34 provinsi di Indonesia. Sumber data yang digunakan pada setiap variabel diuraikan sebagai berikut:

1. Produk Domestik Regional Bruto (PDRB) atas dasar harga konstan 2010 yang bersumber dari website resmi BPS.

2. Rasio gini yang bersumber dari website resmi BPS.

3. Persentase rumah tangga yang memiliki akses terhadap layanan sanitasi layak yang bersumber dari website resmi BPS.

4. Panjang jalan kondisi baik dan sedang yang bersumber dari publikasi Statistik Transportasi Darat.

5. Fasilitas kesehatan yang terdiri dari rumah sakit dan puskesmas milik pemerintah dan swasta yang bersumber dari publikasi Statistik Indonesia.

6. Energi listrik yang didistribusikan yang bersumber dari publikasi Statistik Listrik.

7. Persentase rumah tangga yang memiliki/menguasai telepon seluler bersumber dari publikasi Statistik Telekomunikasi Indonesia.

8. Penanaman Modal Asing (PMA) yang bersumber dari publikasi Statistik Indonesia.

9. Tingkat Partisipasi Angkatan Kerja (TPAK) yang bersumber dari publikasi Indikator Pasar Tenaga Kerja Indonesia.

10. Fasilitas pendidikan berupa jumlah bangunan SD, SMP, SMA, dan SMK milik pemerintah dan swasta diperoleh dari publikasi Statistik Pendidikan.

\section{Metode Analisis}

Metode analisis yang diterapkan pada penelitian ini yakni analisis deskriptif dan analisis inferensia. Analisis deskriptif dilakukan untuk menjelaskan gambaran umum mengenai pertumbuhan ekonomi dan ketimpangan pendapatan. Analisis inferensia dilakukan untuk menganalisis hubungan timbal balik dan pengaruh antara pertumbuhan ekonomi dengan ketimpangan pendapatan serta menganalis dampak dari pembangunan infrastruktur serta determinannya terhadap pertumbuhan ekonomi dan ketimpangan pendapatan. Analisis inferensia yang diterapkan menggunakan model simultan data panel 2SLS (Baltagi, 2005). Tahapan analisis dalam penelitian ini dimulai dengan spesifikasi model untuk menentukan variabel yang relevan untuk diterapkan dalam penelitian. Spesifikasi model yang diterapkan pada penelitian ini merupakan model persamaan simultan yang memiliki dua persamaan struktural dengan dua variabel endogen dan delapan variabel eksogen. Adapun spesifikasi model persamaan simultan yang terbetuk yakni: 


$$
\begin{aligned}
& \operatorname{Lnpdrb}_{i t}=\beta_{10}+\beta_{11} \text { Gini }_{i t}+\beta_{12} \text { Sanitasi }_{i t}+\beta_{13} \text { Lnjalan }_{i t}+\beta_{14} \text { Lnkes }_{i t}+\beta_{15} \text { Lnlistrik }_{i t}+ \\
& \beta_{16} \text { Tel }_{i t}+u_{1 i t} \\
& \text { Gini }_{i t}=\beta_{20}+\beta_{21} \text { Lnpdrb }_{i t}+\beta_{22} \text { LnPMA }_{i t}+\beta_{23} T P A K_{i t}+\beta_{24} \text { Lnpend }_{i t}+u_{2 i t}
\end{aligned}
$$

Keterangan:

$$
\begin{array}{ll}
\beta_{0} & =\text { intercept } \\
\text { PDRB }_{\text {it }} & =\text { PDRB atas dasar harga konstan provinsi ke-i pada tahun ke-t (juta rupiah) } \\
\text { Gini }_{i t} & =\text { Rasio gini provinsi ke-i pada tahun ke-t } \\
\text { Sanitasi }_{\text {it }} & =\text { Persentase rumah tangga dengan akses sanitasi layak provinsi ke-i pada tahun ke-t } \\
\text { Jalan }_{\text {it }} & =\text { Total panjang jalan kondisi baik dan sedang provinsi ke-i pada tahun ke-t (km) } \\
\text { Kes }_{\text {it }} & =\text { Jumlah fasilitas kesehatan provinsi ke-i pada tahun ke-t } \\
\text { Listrik }_{\text {it }} & =\text { Jumlah energi listrik yang didistribusikan provinsi ke-i pada tahun ke-t (gwh) } \\
\text { Tel }_{\text {it }} & =\text { Persentase rumah tangga yang memiliki telepon seluler provinsi ke-i pada tahun ke-t } \\
\text { PMA }_{\text {it }} & =\text { Penanaman Modal Asing provinsi ke-i pada tahun ke-t (juta USD) } \\
\text { TPAK }_{\text {it }} & =\text { Tingkat Partisipasi Angkatan Kerja provinsi ke-i pada tahun ke-t } \\
\text { Pend }_{\text {it }} & =\text { Jumlah fasilitas pendidikan provinsi ke-i pada tahun ke-t } \\
i & =\text { provinsi, } i=1,2, \ldots, 34 \\
t & =\text { tahun, } t=2010,2011, \ldots, 2019
\end{array}
$$

Tahapan selanjutnya adalah indentifikasi persamaan simultan untuk mengetahui apakah nilai estimasi parameter dari persamaan struktural dapat dihasilkan melalui hasil estimasi pada persamaan tereduksi. Dalam penelitian ini, identifikasi model dilakukan dengan dua cara yakni dengan order condition dan rank condition dengan hasil identifikasi yang diperoleh yakni:

Tabel 1. Hasil indentifikasi persamaan simultan.

\begin{tabular}{cccc}
\hline Variabel Endogen & $(\mathrm{K}-\mathrm{k})>(\mathrm{m}-1)$ & Rank Condition & Order Condition \\
\hline PDRB & $3>1$ & Overidentified & Overidentified \\
Rasio Gini & $5>1$ & Overidentified & Overidentified \\
\hline
\end{tabular}

Berdasarkan hasil identifikasi dengan dengan order condition dan rank condition dapat dikatakan bahwa kedua persamaan struktural memiliki kondisi overidentified, sehingga metode estimasi 2SLS tepat untuk digunakan. Langkah berikutnya yakni pengujian simultanitas untuk menentukan apakah terdapat hubungan simultanitas antar persamaan. Apabila memiliki hubungan simultanitas antar persamaan maka metode OLS akan memberikan hasil yang tidak konsisten serta OLS tidak dapat digunakan (Gujarati dan Porter, 2008). Langkah berikutnya adalah menetapkan model terbaik melalui uji Chow serta dilanjutkan dengan uji Hausman. Uji Chow bertujuan untuk memilih model terbaik di antara Pooled effect 2SLS (Pooled 2SLS) dan Fixed Effect 2SLS (FE2SLS). Sedangkan uji Hausman bertujuan untuk menentukan model terbaik di antara Random Effect 2SLS (RE2SLS) dan Fixed Effect 2SLS (FE2SLS). Berdasarkan model yang yang terpilih, dilakukan uji asumsi klasik untuk mendapatkan parameter yang konsisten. Pengujian asumsi normalitas, nonmultikolinearitas, homoskedastisitas, dan nonautokorelasi dilakukan jika model pooled effects terpilih. Akan tetapi, jika model fixed effects dan random effects yang terpilih maka hanya perlu menguji asumsi normalitas dan multikolinearitas karena model tersebut telah mengakomodasi asumsi homoskedastisitas dan nonautokorelasi.

\section{HASIL DAN PEMBAHASAN}

\section{Gambaran Umum Pertumbuhan Ekonomi Indonesia}

Perkembangan pertumbuhan ekonomi di Indonesia antara tahun 2010-2019 pada tabel 2, memiliki nilai yang positif. Meskipun memiliki nilai pertumbuhan yang positif, namun terjadi perlambatan laju pertumbuhan ekonomi. Pertumbuhan ekonomi tertinggi terjadi di tahun 2011 dimana pertumbuhan ekonomi sebesar 6,17 persen dan tahun 2015 merupakan yang terendah sebesar 4,88 persen. 
Tabel 2. Pertumbuhan Ekonomi di Indonesia tahun 2010 - 2019.

\begin{tabular}{ccccc}
\hline Tahun & Pertumbuhan Ekonomi & & Tahun & Pertumbuhan Ekonomi \\
\cline { 4 - 5 } 2010 & $6,10 \%$ & 2015 & $4,88 \%$ \\
2011 & $6,17 \%$ & $6,03 \%$ & 2016 & $5,03 \%$ \\
2013 & $5,56 \%$ & 2017 & $5,07 \%$ \\
2014 & $5,01 \%$ & & 2018 & $5,17 \%$ \\
\hline
\end{tabular}

Sumber: BPS, Publikasi Statistik Indonesia

Rata-rata pertumbuhan ekonomi provinsi-provinsi di Indonesia dari tahun 2011 hingga tahun 2019 bernilai positif. Provinsi Sulawesi Tengah menjadi provinsi dengan rata-rata pertumbuhan ekonomi tertinggi yakni 10,66 persen. Pada 2018, pertumbuhan ekonomi Provinsi Sulawesi Tengah mencapai titik tertinggi sebesar 20,6 persen. Tingginya pertumbuhan ekonomi Sulawesi Tengah tahun 2018 didukung dengan peningkatan kategori industri pengolahan sebesar 106,29 persen dari sisi produksi dan peningkatan eskpor sebesar 151,14 persen dari sisi pengeluaran (BPS Sulawesi Tengah, 2021). Provinsi Papua mempunyai ratarata pertumbuhan ekonomi terendah yakni 2,48 persen, dimana pertumbuhan ekonomi terendah berada pada tahun 2019 sebesar negatif 15,75 persen. Berdasarkan data BPS, pertumbuhan ekonomi yang bernilai negatif di Provinsi Papua tersebut disebabkan kategori lapangan usaha Pertambangan dan Penggalian yang mengalami penurunan sebesar $-43,21$ persen akibat peralihan sistem tambang Freeport ke penambangan bawah tanah dan turunnya nilai ekspor luar negeri Provinsi Papua hingga -69,10 persen (BPS Papua, 2020).

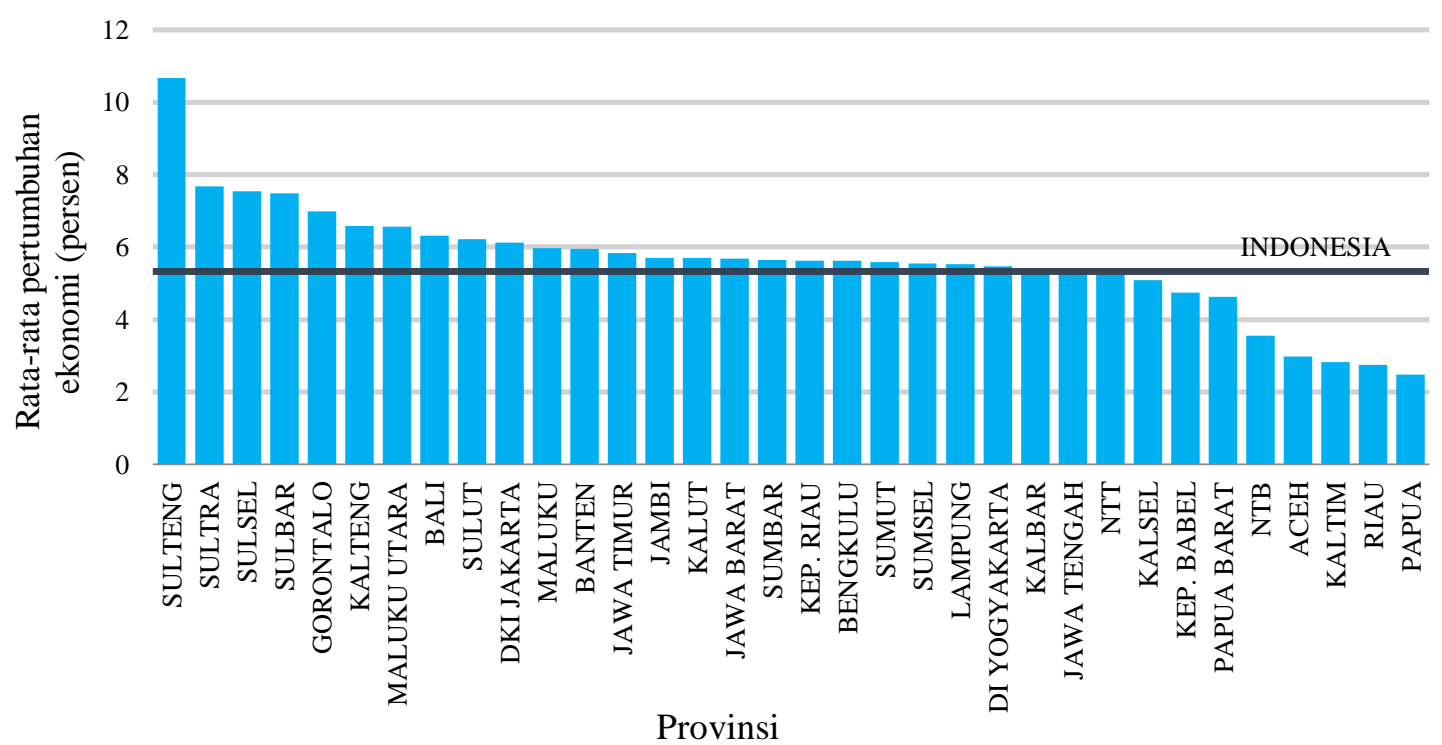

Sumber: BPS, Publikasi Statistik Indonesia

Gambar 1. Rata-rata pertumbuhan ekonomi menurut provinsi tahun 2011 - 2019

\section{Gambaran Umum Ketimpangan Pendapatan di Indonesia}

Ketimpangan pendapatan dapat dijelaskan berdasarkan nilai rasio gini. Rasio gini merupakan ukuran ketimpangan pendapatan secara menyeluruh yang memiliki selang nilai diantara 0 hingga 1 . Tabel 3 menunjukkan bahwa rasio gini Indonesia selama periode tahun 2010 sampai 2019 bergerak fluktuatif yang menunjukkan bahwa kondisi ketimpangan pendapatan berubah selama periode waktu tersebut. Selama tahun 2010 - 2012 dan 2013 - 2014 rasio gini di Indonesia mengalami peningkatan. Penyebab utama kenaikan ketimpangan tersebut adalah pendapatan kalangan rumah tangga terkaya meningkat lebih cepat dibandingkan dengan rumah tangga termiskin (Bemkm, 2019). Tahun 2012 - 2013 dan 2014 - 2019 rasio gini mengalami penurunan. Berbagai kebijakan pemerintah selama beberapa tahun terakhir ini melalui program-program bantuan sosial yang menyasar rumah tangga miskin cukup berhasil untuk menurunkan ketimpangan pendapatan. 
Tabel 3. Rasio gini Indonesia tahun 2010 - 2019.

\begin{tabular}{cc}
\hline Tahun & Rasio Gini \\
\hline 2010 & 0,378 \\
2011 & 0,388 \\
2012 & 0,413 \\
2013 & 0,406 \\
2014 & 0,414 \\
\hline
\end{tabular}

\begin{tabular}{cc}
\hline Tahun & Rasio Gini \\
\hline 2015 & 0,402 \\
2016 & 0,394 \\
2017 & 0,391 \\
2018 & 0,384 \\
2019 & 0,380 \\
\hline
\end{tabular}

Sumber: BPS, Survei Sosial Ekonomi Nasional

Provinsi dengan ketimpangan pendapatan terendah pada tahun 2019 adalah Provinsi Kepulauan Bangka Belitung dengan rasio gini sebesar 0,262 dan termasuk kedalam kategori rendah. Kebijakan Pemprov Kepulauan Bangka Belitung untuk menguatkan kekuatan ekonomi lokal masyarakat, misalnya dengan menguatkan warung-warung daripada jaringan waralaba menjadi kunci keberhasilan pemerataan pendapatan di Provinsi Kepulauan Bangka Belitung (Idris, 2018). Provinsi dengan ketimpangan pendapatan tertinggi adalah Provinsi DI Yogyakarta yang memiliki rasio gini sebesar 0,428. Tingginya ketimpangan pendapatan di Provinsi DI Yogyakarta disebabkan oleh dampak pembangunan yang masif seperti pembangunan hotel dan mall yang hanya dirasakan manfaatnya oleh kelompok ekonomi menengah ke atas. Namun, kelompok ekonomi bawah tidak tersentuh dampak pembangunan tersebut, sehingga kesenjangan pendapatan antar kelompok semakin lebar (Candra, 2017).

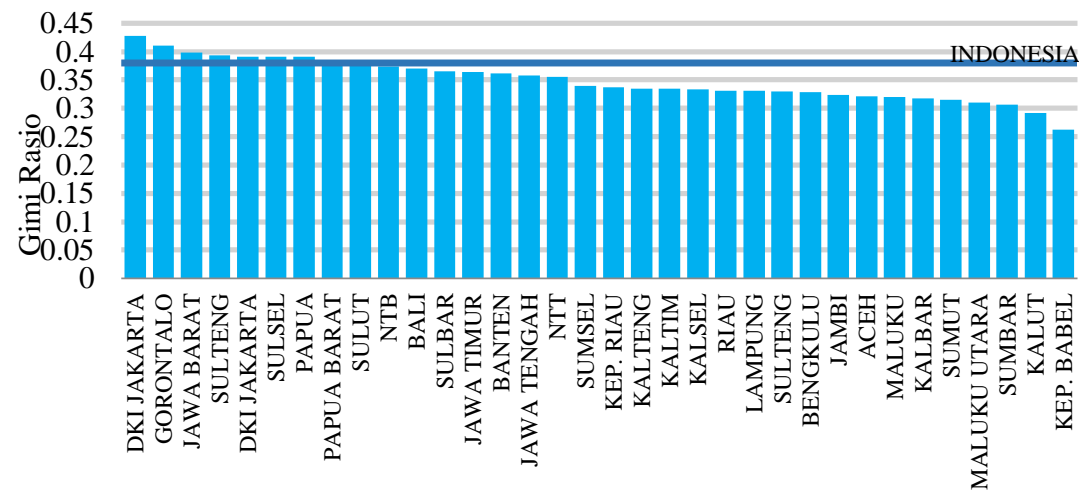

Sumber: BPS, Survei Sosial Ekonomi Nasional

Gambar 2. Rasio gini menurut provinsi Tahun 2019.

\section{Hubungan Simultan Pertumbuhan Ekonomi dan Ketimpangan Pendapatan}

Hasil uji simultanitas Hausman (Lampiran 1) dan pengujian identifikasi menunjukkan bahwa secara empiris terdapat hubungan simultan antar persamaan struktural pada sebuah sistem persamaan. Oleh karena itu, metode OLS bukan lagi estimator yang menghasilkan estimator yang konsisten dan efisien, sehingga untuk mengatasi permasalahan tersebut maka digunakan estimator 2SLS yang memberikan hasil yang konsisten dan efisien (Gujarati dan Porter, 2009). Hasil uji Chow dan dilanjutkan dengan uji Hausman pada lampiran 2 diperoleh kesimpulan bahwa model terbaik untuk mengestimasi kedua persamaan struktural adalah dengan menggunakan Fixed Effect 2SLS (FE2SLS). Pengujian struktur varians-kovarians residual menghasilkan kesimpulan bahwa kedua persamaan struktural memiliki struktur varians-kovarians residual memiliki sifat heteroskedastis dan memiliki cross-sectional correlation, sehingga model diestimasi dengan FEMSUR. Pengujian asumsi klasik yang harus dipenuhi adalah asumsi non-multikolinearitas dan normalitas karena metode FEMSUR telah mengatasi permasalahan heteroskedastisitas dan autokorelasi (Greene, 2012).

Uji normalitas dengan menggunakan Jarque Bera menghasilkan kesimpulan bahwa persamaan struktural ketimpangan pendapatan telah memenuhi asumsi normalitas. Namun, persamaan struktural pertumbuhan ekonomi belum memenuhi asumsi normalitas. Menurut Gujarati dan Porter (2008) jika residual tidak berdistribusi normal, estimator OLS tetap BLUE (Best Linear Unbiased Estimator) dengan estimator yang tetap tidak bias dan varians minimum. Selain itu, karena jumlah sampel yang digunakan besar, sehingga distribusi sampel mengarah kepada distribusi normal sesuai dengan teorema Central Limit Theorem (CLT). Deteksi asumsi non-multikolinearitas dilakukan dengan menghitung nilai $R$-squared. Berdasarkan hasil deteksi, semua variabel pada kedua persamaan struktural memiliki nilai $R$-squared yang lebih rendah dari 0,8 . Oleh karena itu, kedua persamaan memenuhi asumsi non-multikolinearitas. 
Hasil estimasi persamaan pertumbuhan ekonomi dapat dijelaskan lebih lanjut pada tabel berikut:

Tabel 4. Hasil estimasi persamaan pertumbuhan ekonomi.

\begin{tabular}{cccccc}
\hline Variabel Endogen & Variabel Eksogen & Koefisien & p-value & \multicolumn{2}{c}{ Ringkasan Stat, } \\
\hline & Gini & 2,0583 & 0,1906 & & \\
& Sanitasi & 0,0048 & $0,0000^{*}$ & & \\
Lnjalan & 0,0829 & $0,0261^{*}$ & Adj. $\mathrm{R}^{2}$ & 0,9969 \\
& Lnkes & 0,7063 & $0,000^{*}$ & F-stat. & 0,0000 \\
& Lnlistrik & 0,2927 & $0,0000^{*}$ & & \\
& Tel & 0,0006 & 0,7769 & & \\
\hline & C & 10,6597 & $0,0000^{*}$ & & \\
\hline
\end{tabular}

Keterangan: *Signifikan pada $\alpha=5 \%$

Berdasarkan hasil estimasi dengan menggunakan model Fixed Effect 2SLS (FE2SLS) pada persamaan pertumbuhan ekonomi, diperoleh persamaan struktural untuk pertumbuhan ekonomi adalah sebagai berikut:

$$
\begin{aligned}
\operatorname{LN}_{\mathrm{PDR}} B_{i t}= & \left(10,6597+\mu_{1 i t}\right)^{*}+2,0583 \text { GINI }_{i t}+0,0048 \text { SANITASI }_{i t}^{*}+0,0829 \text { LNJALAN }_{i t}^{*}+ \\
& 0,7063 \text { LNKES }_{i t}^{*}+0,2927 \text { LNLISTRIK }_{i t}^{*}+0,0006 T E L_{i t}
\end{aligned}
$$

Berdasarkan hasil estimasi, persamaan pertumbuhan ekonomi signifikan dengan menggunakan uji $\mathrm{F}$, dengan probabilitas yang dihasilkan sebesar 0,0000. Hasil yang diperoleh menunjukkan bahwa pada alpha lima persen, terdapat minimal satu variabel eksogen yang berpengaruh secara signifikan pada variabel endogen. Pengujian keberartian model juga dilakukan dengan melihat nilai dari adjusted $R$-Squared menghasilkan nilai sebesar 0,9969 yang menunjukkan bahwa proporsi variasi pertumbuhan ekonomi yang dijelaskan melalui variabel dalam persamaan sebesar 99,69 persen sedangkan sisanya dapat diterangkan melalui variabel lainnya di luar persamaan.

Hasil penelitian pada tabel 4, menunjukkan bahwa rasio gini tidak berpengaruh secara signifikan terhadap pertumbuhan ekonomi di Indonesia. Hasil yang tidak signifikan dapat disebabkan karna berbagai kebijakan pemerintah selama beberapa tahun terakhir melalui program-program bantuan sosial yang menyasar rumah tangga miskin berhasil menurunkan ketimpangan selama beberapa tahun terakhir, sehingga ketimpangan yang ada tidak signifikan berpengaruh pada pertumbuhan ekonomi. Kepemilikan sanitasi berpengaruh positif dan signifikan pada pertumbuhan ekonomi. Hasil estimasi dari variabel kepemilikan sanitasi layak adalah 0,0048 yang menunjukkan bahwa peningkatan satu persen pada rumah tangga dengan akses sanitasi layak meningkatkan nilai PDRB sebesar 0,48 persen. Hasil ini mendukung penelitian dari Nugraha et al., (2020) yang turut menunjukkan hasil yang serupa, dimana peningkatan rumah tangga dengan akses sanitasi layak dapat meningkatkan pertumbuhan ekonomi di Indonesia. Ketersedian akses terhadap sanitasi layak berdampak dalam mendorong kehidupan yang layak serta menunjang kualitas kesehatan masyarakat, dengan demikian akan turut mempengaruhi tingkat produktivitas masyarakat dan output perekonomian suatu wilayah.

Panjang jalan kondisi baik dan sedang berpengaruh positif dan signifikan bagi pertumbuhan ekonomi. Koefisien untuk variabel panjang jalan kondisi baik sedang yakni 0,0829 yang menunjukkan bahwa bila panjang jalan kondisi baik sedang meningkat satu persen, maka akan turut meningkatkan nilai PDRB sebesar 0,0829 persen. Hasil tersebut mendukung hasil empiris sebelumnya dari Radiansyah (2012) yang menjelaskan bahwa panjang jalan berpengaruh positif pada kenaikan PDRB per kapita provinsi di Indonesia. Ketersediaan infrastruktur jalan pada setiap wilayah akan menciptakan keterhubungan antar pusat perekonomian, sehingga akan mempercepat distribusi faktor produksi, seperti barang dan jasa. Tidak hanya itu, ketersediaan infrastruktur jalan dapat menghasilkan akses yang lebih mudah dan terbuka antarwilayah, serta berpeluang untuk meningkatkan pertumbuhan ekonomi dan mengurangi wilayah yang masih terisolasi (Warsilan \& Noor, 2015).

Fasilitas kesehatan yang didekati dengan jumlah rumah sakit dan puskesmas memiliki pengaruh positif serta signifikan bagi pertumbuhan ekonomi dengan nilai koefisien sebesar 0,7063. Kenaikan satu persen pada jumlah fasilitas kesehatan akan meningkat nilai PDRB sebesar 0,7063 persen. Hasil yang didapat sejalan dengan penelitian Ardiansyah (2019) bahwa jumlah fasilitas kesehatan menunjukkan efek yang positif dan signifikan pada PDRB ADHK non pertambangan di Provinsi Nusa Tenggara Barat. Adanya fasilitas kesehatan yang memadai dan baik akan berdampak pada peningkatan kesehatan masyarakat, sehingga akan meningkatkan produktivitas masyarakat dan pada akhirnya memberikan pengaruh positif bagi peningkatan output perekonomian suatu daerah.

Variabel total energi listrik yang didistribusikan memiliki pengaruh yang positif serta signifikan pada pertumbuhan ekonomi. Peningkatan satu persen total energi listrik yang didistribusikan akan meningkatkan pertumbuhan ekonomi sebesar 0,2927 persen. Penelitian serupa dari Maryaningsih et al., (2014) turut menyatakan bahwa infrastruktur listrik memiliki dampak positif dan signifikan dalam meningkatkan 
pendapatan per kapita. Ketersedian infrastruktur dasar seperti listrik adalah hal yang sangat penting dalam menghasilan pertumbuhan ekonomi yang tinggi dan berkesinambungan, karena ketersediaan energi listrik berperan penting dalam mendukung peningkatan kapasitas produksi. Selain itu, ketersediaan energi listrik yang cukup bagi masyarakat akan turut meningkatkan kesejahteraan masyarakat karena digunakan dalam berbagai fasilitas untuk membantu menyelesaikan berbagai pekerjaan dengan lebih baik.

Variabel infrastruktur telekomunikasi yakni persentase rumah tangga memiliki/menguasai telepon seluler tidak berpengaruh secara signifikan pada pertumbuhan ekonomi. Hasil yang didapatkan sejalan dengan penelitian serupa dari Prasetyo (2019) menjelaskan bahwa pembangunan infrastruktur telekomunikasi di ASEAN tidak berdampak pada pertumbuhan ekonomi secara langsung, dimana dampak dari pembangunan infrastruktur telekomunikasi hanya tersedia melalui outcome dari pertumbuhan ekonomi serta hanya berperan kecil pada perekonomian (Pradhan et al., 2013).

Berdasarkan hasil estimasi menggunakan model Fixed Effect 2SLS (FE2SLS) pada model persamaan ketimpangan pendatapan, diperoleh persamaan struktural untuk ketimpangan pendapatan adalah sebagai berikut:

$$
\begin{aligned}
\widehat{G I N I}_{i t}= & \left(1,2145+\mu_{2 i t}\right)^{*}-0,0323 L N P D R B_{i t}^{*}+0,0031 L N P M A_{i t}^{*}-0,0004 T P A K_{i t}- \\
& 0,0283 L N P E N D_{i t}^{*}
\end{aligned}
$$

Hasil estimasi persamaan ketimpangan pendapatan dapat dijelaskan lebih lanjut pada tabel 5.

\begin{tabular}{|c|c|c|c|c|c|}
\hline Variabel Endogen & Variabel Eksogen & Koefisien & p-value & Ringka & an Stat, \\
\hline \multirow{5}{*}{ Gini } & Lnpdrb & $-0,0323$ & $0,0001^{*}$ & \multirow{5}{*}{$\begin{array}{l}\text { Adj. } \mathrm{R}^{2} \\
\text { F-stat. }\end{array}$} & \multirow{5}{*}{$\begin{array}{l}0,8063 \\
0,0000\end{array}$} \\
\hline & Lnpma & 0,0031 & $0,0138^{*}$ & & \\
\hline & TPAK & $-0,0004$ & 0,3689 & & \\
\hline & Lnpend & $-0,0283$ & $0,0023 *$ & & \\
\hline & $\mathrm{C}$ & 1,2145 & $0,0000^{*}$ & & \\
\hline
\end{tabular}

Tabel 5. Hasil estimasi persamaan ketimpangan pendapatan.

Keterangan: * Signifikan pada $\alpha=5 \%$

Hasil estimasi persamaan ketimpangan pendapatan pada Tabel 5 menunjukkan nilai $p$-value dari Fstatistik yang dihasilkan sebesar 0,0000 dan kurang dari tingkat signifikansi yang ditetapkan. Hasil tersebut menunjukkan bahwa pada alpha lima persen, terdapat minimal satu variabel eksogen yang berpengaruh secara signifikan terhadap variabel endogen. Nilai adjusted $R$-Squared dalam persamaan menghasilkan nilai sebesar 0,8063 yang berarti bahwa proporsi variasi ketimpangan pendapatan dapat diterangkan oleh variabel dalam persamaan sebesar 80,63 persen, serta sisanya yaitu 19,37 persen dapat diterangkan oleh variabel lainnya di luar persamaan.

Hasil penelitian pada tabel 5, menunjukkan bahwa nilai PDRB berpengaruh secara negatif dan signifikan bagi ketimpangan pendapatan. Pengaruh negatif tersebut dapat ditunjukkan melalui nilai koefisien pertumbuhan ekonomi sebesar -0,0323. Hasil tersebut menunjukkan bahwa peningkatan satu persen nilai PDRB dapat menurunkan rasio gini sebesar 0,0003 satuan. Hasil penelitian lain yang serupa oleh Nugraha et al., (2020) juga turut menunjukkan hasil yang sama dimana peningkatan pertumbuhan ekonomi di Indonesia berpengaruh secara signifikan pada pengurangan ketimpangan pendapatan. Hasil tersebut juga sejalan dengan Hipotesis Kuznet, yang menunjukkan bahwa pada tahap awal pertumbuhan ekonomi akan mengakibatkan distribusi pendapatan akan cenderung memburuk disuatu wilayah, namun pada jangka panjang hubungan pertumbuhan ekonomi dan ketimpangan pendapatan akan bernilai negatif (Todaro dan Smith, 2004). Dapat dijelaskan bahwa Indonesia telah berada pada tahap jangka panjang menurut Hipotesis Kuznet dimana pertumbuhan ekonomi mengurangi ketimpangan pendapatan. Agar manfaat pertumbuhan ekonomi dapat dirasakan oleh setiap lapisan penduduk, terutama penduduk berpenghasilan rendah maka pertumbuhan ekonomi harus diarahkan dalam rangka memperkecil kesenjangan antara penduduk kaya dan miskin.

Penanaman Modal Asing (PMA) turut memengaruhi ketimpangan pendapatan secara signifikan dan positif. Nilai koefisien untuk variabel PMA sebesar 0,0031 yang menunjukkan bahwa peningkatan PMA satu persen dapat meningkatkan rasio gini sebesar 0,00003 satuan. Hasil yang serupa ditunjukkan oleh penelitian Teeramungcalanon \& Chiu (2020) bahwa PMA meningkatkan ketimpangan pendapatan di Vietnam. Couto (2018) menjelaskan bahwa PMA meningkatkan ketimpangan pendapatan karena PMA meningkatkan permintaan terhadap tenaga kerja dengan keterampilan yang lebih tinggi dibandingkan pekerja yang tidak terampil, yang pada gilirannya mengarah pada peningkatan upah dan tingkat pekerjaan pekerja berketerampilan tinggi. Kondisi tersebut akan menghasilkan ketimpangan pendapatan yang semakin lebar 
diantara pekerja terampil dengan pekerja tidak terampil. Berdasarkan hasil penelitian, TPAK tidak berpengaruh secara signifikan bagi ketimpangan pendapatan. Hasil yang diperoleh sejalan dengan penelitian serupa yang dilakukan oleh Rahma (2018) yang memperoleh hasil bahwa TPAK tidak berpengaruh secara signifikan bagi ketimpangan pendapatan di Pulau Jawa. Kondisi tenaga kerja di Indonesia yang umumnya memiliki pendidikan yang rendah serta ketrampilan yang rendah mengakibatkan banyak pekerja memiliki produktivitas yang rendah dengan upah yang rendah pula, sehingga ketersedian tenaga kerja berdampak tidak signifikan terhadap ketimpangan pendapatan.

Infrastruktur pendidikan yang berupa jumlah bangunan SD, SMP, SMA, dan SMK berpengaruh signifikan serta negatif pada ketimpangan pendapatan. Kenaikan satu persen fasilitas pendidikan akan menurunkan rasio gini sebesar 0,00028 satuan. Hasil tersebut sejalan dengan penelitian Agustiar (2019) dimana jumlah sekolah memiliki pengaruh signifikan pada penurunan ketimpangan pendapatan masyarakat yang berada di Pulau Jawa. Hasil tersebut sesuai dengan teori human capital yang menggunakan konsep bahwa pendidikan adalah salah satu modal utama manusia yang berpengaruh bagi pertumbuhan ekonomi dan dapat menurunkan ketimpangan pendapatan sebab pendidikan memiliki peran penting didalam meningkatkan produktivitas pekerja.

\section{KESIMPULAN}

Pertumbuhan ekonomi di Indonesia dalam kurun waktu 2010-2019 tumbuh positif dengan rata-rata pertumbuhan 5,4 persen setiap tahun, serta ketimpangan pendapatan yang digambarkan melalui rasio gini bergerak secara fluktuatif. Rata-rata pertumbuhan ekonomi provinsi-provinsi di Indonesia bernilai positif, serta ketimpangan pendapatan provinsi termasuk kedalam ketegori rendah dan sedang. Terdapat hubungan simultan antara pertumbuhan ekonomi dan ketimpangan pendapatan, dimana pertumbuhan ekonomi memiliki pengaruh negatif serta signifikan terhadap ketimpangan pendapatan. Infrastuktur sanitasi, jalan, kesehatan, dan listrik berpengaruh positif dan signifikan pada pertumbuhan ekonomi, sedangkan infrastruktur telekomunikasi tidak berpengaruh signifikan. Infrastruktur pendidikan memiliki pengaruh negatif dan signifikan pada ketimpangan pendapatan, sedangkan PMA memiliki pengaruh positif serta signifikan pada ketimpangan pendapatan. TPAK tidak berpengaruh secara signifikan terhadap ketimpangan pendapatan.

Saran yang dapat diberikan yaitu, pemerintah dapat terus meningkatkan kualitas pembangunan infrastruktur dan memastikan pembangunan yang dilakukan dapat dimanfaatkan oleh setiap masyarakat. Selain itu, perlunya perhatian lebih terhadap sektor-sektor dimana penduduk berpenghasilan rendah banyak bekerja seperti sektor pertanian, sehingga pertumbuhan ekonomi yang terjadi dapat semakin dirasakan manfaatnya oleh setiap masyarakat terutama masyarakat berpenghasilan menengah kebawah. Agar dapat mengurangi efek PMA terhadap ketimpangan dan tetap mendapatkan manfaatnya, maka perlunya peran pemerintah dalam mendukung peningkatan modal manusia melalui pendidikan dan pelatihan. Dengan demikian, akan tersedianya pekerja dengan ketrampilan tinggi yang jauh lebih besar dibandingkan pekerja dengan keterampilan rendah.

\section{DAFTAR PUSTAKA}

Agustiar, D. W. (2019). Pengaruh Pembangunan Infrastruktur terhadap Ketimpangan Distribusi Pendapatan di Pulau Sulawesi dan Jawa [Skripsi]. Jakarta: Sekolah Tinggi Ilmu Statistik.

Ardiansyah, B. (2019). Prospek Pembangunan Infrastruktur Dalam Perspektif Pertumbuhan Ekonomi Provinsi Nusa Tenggara Barat Tahun 2010 - 2017 [Skripsi]. Jakarta: Sekolah Tinggi Ilmu Statistik.

Awandari, L. P. P., \& Indrajaya, I. G. B. (2016). Pengaruh infrastruktur, investasi, dan pertumbuhan ekonomi terhadap kesejahteraan masyarakat melalui kesempatan kerja. E-Jurnal Ekonomi Pembangunan Universitas Udayana.

Badan Pusat Statistik (BPS). Berbagai Edisi. Statistik Indonesia. Jakarta: Badan Pusat Statistik.

BPS Papua. (2020). Berita Resmi Statistik Pertumbuhan Ekonomi Papua Tahun 2019. Badan Pusat Statistik Provinsi Papua, Jayapura.

BPS Sulawesi Tengah. (2021). PDRB Provinsi Sulawesi Tengah 2016-2020. Badan Pusat Statistik Provinsi Sulawesi Tengah, Palu.

Bemkm. (Rabu, 08 Desember 2019). Potret Ketimpangan di Indonesia. Diakses tanggal 30 Mei 2021 melalui https://bemkm.ugm.ac.id/potret-ketimpangan-di-indonesia/

Candra, Sapto Andika. (Selasa, 18 Juli 2017). Ketimpangan Yogya Tertinggi, Ekonom: Banyak Mal. Diakses tanggal 1 Juni 2021 melalui https://www.republika.co.id/berita/ekonomi/makro/17/07/18/ot9yf6382-ketimpangan-yogya-tertinggi- 
ekonom-akibat-banyak-mal

Couto, V. (2018). Does Foreign Direct Investment Lower Income Inequality? Final Paper: Redlas Conference, 1-31.

Gujarati, Damodar N. (2008). Basic Econometrics (5th Edition). New York: Mc.Graw Hill Irwin.

Greene, William H. (2012). Econometric Analysis (Seventh Edition). New York: Pearson Education

Idris, Muhammad. (Selasa, 25 September 2018). Ketimpangan Ekonomi di Babel Terendah di Indonesia, ini kuncinya. Diakses tanggal 1 Juni 2021 melalui https://finance.detik.com/beritaekonomi-bisnis/d-4229187/ketimpangan-ekonomi-babel-terendah-di-indonesia-ini-kuncinya

Maryaningsih, N., Hermansyah, O., \& Savitri, M. (2014). Pengaruh Infrastruktur Terhadap Pertumbuhan Ekonomi Indonesia. Buletin Ekonomi Moneter Dan Perbankan.

Nugraha, A. T., Prayitno, G., Situmorang, M. E., \& Nasution, A. (2020). The role of infrastructure in economic growth and income inequality in Indonesia. Economics and Sociology.

Prasetyo, G. adi. (2016). Pengaruh Pembangunan Infrastruktur Telekomunikasi Terhadap Pertumbuhan Ekonomi Di Asean. Jurnal Ilmu Ekonomi Terapan, 4(1). https://doi.org/10.20473/jiet.v4i1.13941

Radiansyah, D. (2012). Analisis Kontribusi Infrastruktur terhadap Pertumbuhan Ekonomi Regional di Indonesia (Periode Tahun 1996-2008) [Tesis]. Jakarta: UI.

Rahma, E. A. (2018). Analisis Faktor-Faktor Yang Mempengaruhi Ketimpangan Pendapatan Antar Provinsi Di Pulau Jawa Tahun 2010-2016. Journal of Chemical Information and Modeling, 53(9).

Rogers, P. P., Jalal, K. F., \& Boyd, J. A. (2012). An introduction to sustainable development. London: Glen Educational Foundation.

Setiadi, Elen. (2006). Pengaruh Pembangunan Infrastruktur Dasar Terhadap Pertumbuhan Ekonomi Regional Indonesia (8 Provinsi di Sumatera) [Tesis]. Jakarta: Universitas Indonesia.

Tampubolon, N. H. (2013). Pengaruh Ketersediaan Infrastruktur Terhadap Ketimpangan Pendapatan per kapita: Analisis Provinsi di Indonesia 2007-2011. Jurnal Ekonomi \& studi pembangunan.

Teeramungcalanon, M., \& Chiu, E. M. P. (2020). The effects of foreign direct investment on income inequality of Thailand. Southeast Asian Journal of Economics, 8(1), 107-138.

Todaro, Michael P. \& Stephen C. Smith. (2004). Pembangunan Ekonomi di Dunia Ketiga, Edisi kedelapan. Jakarta : Erlangga.

Untari, R. (2019). Dampak Infrastruktur Teknologi Informasi dan Komunikasi (TIK) terhadap Pertumbuhan Ekonomi dan Ketimpangan Pendapatan di Indonesia [Tesis]. Bogor: Institut Pertanian Bogor.

Warsilan, W., \& Noor, A. (2015). Peranan Infrastruktur terhadap Pertumbuhan Ekonomi dan Implikasi pada Kebijakan Pembangunan di Kota Samarinda. MIMBAR, Jurnal Sosial Dan Pembangunan, 31(2), 359. https://doi.org/10.29313/mimbar.v31i2.1444

World Bank. (2015). Ketimpangan yang Semakin Lebar: Aku Akhir Untuk Indonesia.

\section{Lampiran}

Lampiran 1. Hasil uji simultanitas Hausman.

\begin{tabular}{ccc}
\hline Persamaan & p-value & Keputusan \\
\hline PDRB & 0,0000 & Terdapat masalah simultanitas \\
GINI & 0,0000 & Terdapat masalah simultanitas \\
\hline
\end{tabular}

Lampiran 2. Hasil uji Chow dan Uji Hausman.

\begin{tabular}{ccccc}
\hline Persamaan & Pengujian & Stat. Uji & p-value & Keputusan \\
\hline PDRB & Chow & 313,9910 & 0,0000 & FEM \\
& Hausman & 32,6396 & 0,0000 & FEM \\
GINI & Chow & 25,4272 & 0,0000 & FEM \\
& Hausman & 25,0880 & 0,0000 & FEM \\
\hline
\end{tabular}

